\title{
Діагностика гемофілічної артропатії
}

\section{А.С. Кались}

Державна установа «Інститут патології крові та трансфузійної медицини НАМН України», Львів, Україна

У структурі геморагічних проявів гемофілії одним із провідних симптомів $\epsilon$ крововилив у суглоби - гемартроз. Зміни, що виникають внаслідок крововиливу у суглоб, можна описати як спричинене кров'ю захворювання суглоба (blood induced joint disease) [1]. Найбільш чутливим індикатором стану суглоба $є$ синовіальна оболонка (СО) - внутрішній шар капсули суглоба, що вистилає всю поверхню суглобової порожнини за винятком хрящових поверхонь. СО багата нервами і судинами, які забезпечують обмін речовин у порожнині суглоба. Крім того, СО забезпечує додаткову амортизацію суглобів і виробляє синовіальну рідину. При гемофілії СО бере участь у видаленні крові з порожнини суглоба, що призводить до гіперплазії та гіпертрофії синовіоцитів та гіперваскуляризації підінтими, що в перспективі підвищує ризик розвитку подальших гемартрозів [2].

Пусковим моментом, який призводить до активації каскаду патологічних реакцій, $\epsilon$ виділення в синовіальну рідину заліза. Після крововиливу в суглоб гемосидерин, який $\epsilon$ продуктом розпаду гемоглобіну, поглинається макрофагами і відкладається у тканині СО, що призводить до розвитку хронічного запального процесу в суглобі. Він також накопичується у хрящовій тканині. Просочена гемосидерином СО як наслідок виробляє значну кількість прозапальних медіаторів (інтерлейкіни, фактор некрозу пухлини-а). Патологічні процеси, такі як гіпертрофія СO, ї̈ гіперваскуляризація та дегенерація хряща, які виникають внаслідок гемартрозу, у подальшому призводять до переходу гострого синовіту в хронічну фазу з розвитком хронічного синовіту, який має значний вплив на подальший розвиток специфічного ураження суглобів — гемофілічної артропатії (ГА) (рисунок).

Рисунок Патогенетичний каскад розвитку деформуючого остеоартриту внаслідок гемартрозу [2]

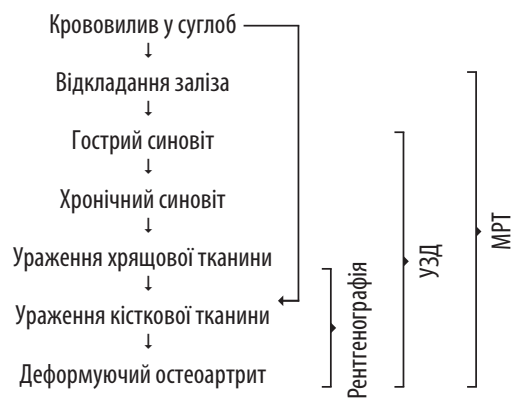

Тут і далі: УзД — ультразвукова діагностика; МРТ — магнітно-резонансна томографія.

ГА - характерне для гемофілії ускладнення, що проявляєТься рецидивуючими крововиливами в порожнину суглоба з розвитком внутрішньосуглобового спайкового процесу і формуванням стійких контрактур і анкілозів. ГА $є$ основною причиною захворюваності та інвалідизації у пацієнтів із гемофілією. Наявні дані свідчать, що своєчасна діагностика змін у суглобах при гемофілії, особливо на ранніх стадіях їх формування, сприяє ранньому початку терапії, що суттєво впливає на прогноз захворювання. Розвиток нових методів лікування і профілактики ГА диктує нові вимоги до оцінки характеру ураження суглоба і завдяки розвитку нових технологій з'явилися нові можливості виявлення змін у кістково-суглобовому апараті та м'яких тканинах у хворих на гемофілію. Так, цифрові технології дають можливість своєчасно діагностувати ураження суглобів у пацієнтів із гемофілією. 3 цією метою можливе використання таких методів діагностики, як рентгенографія, МРТ, комп'ютерна томографія (КТ), сцинтиграфія та УзД. Традиційно з метою виявлення ураження суглобів у пацієнтів із гемофілією використовують рентгенографію, а в останні роки - МРТ $[3,4]$.
Протягом тривалого часу провідним методом діагностики стану суглобів при гемофілії була рентгенографія, яка $\epsilon$ неінвазивним, доступним та економічно вигідним методом, що дозволяє в більшості випадків визначити наявність ураження суглоба при залученні в патологічний процес кісткових елементів, однак на ранніх стадіях захворювання інформативність цього методу невисока. Незважаючи на впровадження нових діагностичних методів, важливість стандартної рентгенографії не знижується, а навпаки, цей метод $\epsilon$ одним із перших рекомендованих методів в алгоритмі діагностики ГА. Рентгенографія $\epsilon$ корисною для оцінки стану суглоба на пізніх стадіях захворювання, коли відбувається значне руйнування хряща, утворення кіст і ерозій у субхондральних відділах кістки. Для оцінки тяжкості уражень суглобів у хворих на гемофілію використовують клініко-рентгенологічну класифікацію гемофілічного остеоартриту, в якій розрізняють чотири стадії (таблиця) [5]. Однак рентгенографія має і ряд недоліків, зокрема неможливість оцінити стан хряща та СО. Крім того, враховуючи прогресуючий перебіг гемофілії, пацієнти потребують частішої оцінки стану суглобів, що несе ризики, пов'язані з опроміненням, тому необхідним $\epsilon$ застосування сучасних цифрових технологій для рутинного моніторингу стану суглоба у пацієнтів із гемофілією.

Таблиця К Клініко-рентгенологічна класифікація гемофілічного остеоартриту [5]

Клініко-рентгенологічна класифікація гемофілічного остеоартриту

\begin{tabular}{cl}
\hline Стадія & \multicolumn{1}{c}{ Характеристика } \\
\hline I & $\begin{array}{l}\text { Наявність збільшеного в об'ємі суглоба за рахунок гемартрозу. Функція суглоба } \\
\text { не порушена. Рентгенологічно визначається потовщення та ущільнення } \\
\text { суглобової капсули та помірний остеоартрит }\end{array}$ \\
\hline & $\begin{array}{l}\text { Наявні характерні зміни в субхондральному шарі епіфізів: краєві узури, } \\
\text { субхондральні кісти. Візуалізуються невеликі крайові дефекти на бічних } \\
\text { поверхнях внаслідок локального впливу крові. Прогресує остеоартрит. Наявне } \\
\text { зменшення обсягу руху в суглобі }\end{array}$ \\
\hline III $\quad \begin{array}{l}\text { Ауглоб значно збільшений в об'ємі, дефігурований, наявна гіпотрофія м'язів. } \\
\text { суглобових кінців, руйнування субхондрального шару, звуження суглобової } \\
\text { щілини. Також наявні крайові кісткові розростання, виражений остеоартрит }\end{array}$ \\
ІІ $\quad \begin{array}{l}\text { Функція суглоба повністю порушена, суглобова щілина різко звужена або } \\
\text { відсутня. Відзначається виражений склероз субхондрального шару кістки }\end{array}$
\end{tabular}

Сьогодні еволюція методів лікування гемофілії привела до необхідності створення більш точних систем оцінки змін суглобів для виявлення початкових проявів захворювання, здійснення моніторингу прогресування хвороби і контролю ефективності терапії, що застосовується. Іншим рекомендованим методом діагностики $\epsilon$ MPТ, що дозволяє найбільш рано і досить точно ідентифікувати зміни в суглобах і періартрикулярних тканинах при ГА. У численних наукових дослідженнях показано, що МРТ володіє найбільшою інформативністю в оцінці внутрішньо- і позасуглобових структур, володіючи високою роздільною здатністю у візуалізації м'якотканних і кісткових анатомічних структур, дозволяє деталізувати стан СО, встановити наявність або відсутність внутрішньосуглобової рідини, оцінити сухожильно-зв'язковий апарат, суглобовий хрящ, стан кісткового мозку, а також виявити і визначити обсяг і давність гемартрозу. Однак недоліком МРТ $\epsilon$ те, що, по-перше, метод має високу вартість та, по-друге, первинна ланка медичної допомоги не оснащена магнітно-резонансними томографами.

В останні роки все більшої значущості в оцінці стану суглобів у пацієнтів із гемофілією набуває УЗД, що пов'язано із впровадженням нових діагностичних технік, режимів сканування, засобів підсилення сигналу та алгоритмів покращення зображення, що націлено 
на покращення оцінки стану суглобів. УзД $є$ неінвазивним, недорогим і широко доступним методом дослідження, має багато переваг для використання в педіатричній практиці, оскільки не спричиняє променевого навантаження і не потребує седації пацієнтів. Перевагами УЗД-діагностики $є$ те, що обстеження пацієнта проводиться в режимі реального часу та можливе проведення одночасного дослідження з функціональними пробами, що в результаті дає поєднання як інструментального, так і клінічного обстеження. Доступність методу полягає в тому, що УЗД наявна у більшості лікувальних закладів, обстеження триває протягом 10-15 хв (для одного суглоба) у зручному для пацієнта положенні, а вартість на порядок нижча від аналогічних методів, зокрема таких як МРТ та КТ. УЗД $є$ безпечною для пацієнта, оскільки не пов'язана з іонізуючим випромінюванням, порівняно з рентгенографією, що дозволяє виконувати обстеження відносно часто, при клінічній потребі або з метою скринінгу стану суглоба.

Найбільша перевага УзД - можливість проведення візуалізації та оцінки стану СO, яка $\epsilon$ найбільш чутливим індикатором стану суглоба. Як зазначено вище, внаслідок крововиливу у суглоб СО патологічно змінюється. Основними ознаками цієї патологічної зміни $є$ проліферація, гіпертрофія та неоваскуляризація ворсинок СО. Відповідно функція доплерографії, що доступна в апаратах УЗД, дає можливість реєструвати низькошвидкісний потік крові по судинах синовію, що, відповідно допоможе ідентифікувати патологію суглоба. УЗД дає можливість визначати ширину суглобової щілини і оцінювати стан суглобового хряща, виявляти зміни в параартикулярних м'яких тканинах. Крім того, отримані дані можна використати з метою оцінки ефективності лікування та профілактики гемофілії, а також як показання до проведення хірургічного лікування (синовектомії) [6].

За підтримки ТОВ «Такеда Україна» VV-MEDMAT-38096

\section{Список використаної літератури/References}

1. Wessel L.M., Scholz S., Rüsch M. (2001) Characteristic pattern and management of intraarticular knee lesions in different pediatric age groups. J. Pediatr. Orthop., 21(1): 14-19. doi: 10.1097/00004694-200101000-00005

3. Madhok R., York J., Sturrock R.D. (1991) Haemophilic arthritis. Ann. Rheum. Dis., 50(8): 588-591. doi: 10.1136/ard.50.8.588

5. Bryukhanov A.V. (1996) Magnetic resonance imaging in the diagnosis and evaluation of the effectiveness of treatment of hemophilic arthropathies. Cand. med. sci. abstracts diss., Barnaul, 28 p. (In Rus.).

6. Zavadovskaya V.D.,Ogorodova L.M.,Zhogina T.V. etal. (2011) Spectrum of intraarticular structures's changes in patients with hemophilic artropathy by magnetic resonance imaging. Bulletin of Siberian Medicine, 10(3): 37-43. https://doi.org/10.20538/1682-0363-2011-3-37-43. (In Rus.).

8. Novikova E.Z. (1982) X-ray changes in diseases of the blood system. Medicine, Moscow, $256 \mathrm{p}$.

9. Kalys A.S., Gorak A.R. (2020) The value of ultrasonography in the diagnosis of hemophilic arthropathies. Health of Ukraine, 5(66): 13-14.

\author{
Відомості про автора: \\ Кались Андрій Степанович — керівник хірургічної групи для хворих на гемофілію ДУ «Ін- \\ ститут патології крові та трансфузійної медицини НАМН України», Львів, Україна \\ Адреса для кореспонденції: \\ Кались Андрій Степанович \\ 79000, Львів, вул. Генерала Чупринки, 45 \\ E-mail: kalysandriy@gmail.com
}

\author{
Information about the author: \\ Kalys Andrii S. - Head of the Surgical group for patients with hemophiliaos the SI «Institute of \\ blood pathology and transfusion medicine of NAMS of Ukraine», Lviv, Ukraine \\ Address for correspondence: \\ Andrii Kalys \\ 79000, Lviv, General Chuprynka str., 45 \\ E-mail: kalysandriy@gmail.com
}

Надійшла до редакції/Received: 01.02.2021 Прийнято до друку/Accepted: 08.02.2021

ТЕСТОВІ ЗАПИТАННЯ

(один або декілька правильних варіантів відповідей на кожне запитання)

1. Визначте провідний симптом гемофілії:
$\square$ більу суглобі
$\square$ гемартроз
$\square$ набряк суглоба
$\square$ гематурія

2. Визначте найчутливіший індикатор стану суглоба:
$\square$ синовіальна оболонка
$\square$ головка стегнової кістки
$\square$ хрящ
$\square$ усі відповіді правильні

3. Визначте пусковий момент, що запускає каскад патологічних реакцій при гемартрозі:
$\square$ гіпертрофія синовіоцитів
$\square$ гіперплазія синовіоцитів
$\square$ виділення в синовіальну рідину заліза
$\square$ синтез прозапальних медіаторів

4. Визначте каскад реакцій патогенезу деформуючого остеоартриту:

$\square$ крововиливу у суглоб - гострий та хронічний синовіт ураження хрящової та кісткової тканини - деформуючий остеоартрит

$\square$ неспецифічне запалення у суглобі - пошкодження тканин - посилення запального процесу — деформуючий остеоартрит

$\square$ активація та проліферація імунокомпетентних клітин — продукція медіаторів запалення - проліферація фібробластів - хронічне запалення - деформуючий остеоартрит $\square$ усі відповіді правильні

5. Визначте специфічне для гемофілії ускладнення:

$\square$ піднігтьовий кератит

$\square$ гемофілічна артропатія

$\square$ деформація пальця за типом «гудзикової петлі»

$\square$ усі відповіді правильні

6. Визначте методи діагностики ураження суглобів при гемофілії:

$\square$ MPT

$\square$ УзД

$\square$ рентгенографія

$\square$ денситометрія

7. Визначте III стадію гемофілічного остеоартриту за клінікорентгенологічною класифікацією:

$\square$ потовщення та ущільнення суглобової капсули та помірний остеоартрит

$\square$ зміни в субхондральному шарі епіфізів: краєві узури, субхондральні кісти

$\square$ деформація суглобових кінців, руйнування субхондрального шару, звуження суглобової щілини, крайові кісткові розростання та виражений остеоартрит

$\square$ виражений склероз субхондрального шару кістки

8. Який метод діагностики дає можливість реєструвати низькошвидкісний потік крові по судинах синовію?
$\square$ УзД
$\square$ MPT
$\square$ рентгенографія
$\square$ усі відповіді правильні 